\title{
Bacteroides intestinalis
}

National Cancer Institute

\section{Source}

National Cancer Institute. Bacteroides intestinalis. NCI Thesaurus. Code C119324.

A species of indole-positive, gram negative, anaerobic rod shaped bacteria belong ing to the genus Bacteroides that hydrolyses esculin and has been isolated from human feces. 